\title{
Perlindungan Hak Paten Bagi Pengrajin Khas
}

\author{
Protection of Paten Rights on Special Inventors
}

\author{
Jabalnur \\ Dosen Fakultas Hukum Halu Oleo \\ E-mail: jabal_nur11@yahoo.co.id
}

\begin{abstract}
The term of the patent can be viewed in some regulations, precisely in Article 1 paragraph 1 Laws 13 the Year 2016 concerning Patent. In this mentioned that the concept of Patent Rights is the exclusive rights that given by the State to the inventor as for his/her invention in the technology field for certain time. Inventor himself is allowed to execute his/her invention or to agree with another side in order implement their inventions. There are three Conditions of invention right namely; the first, the mentioned invention is a truly new invention. The second, mentioned invention is produced by massively and industrially. A technology invention such a sophisticated creation, but it is unable produced on an industrial scale due to high cost or uneconomically, is actually does not have the rights to the patent. The third, this invention is clearly nonobvious. If it is comparable with two things, so it can not be patented.
\end{abstract}

\section{Keyword: Patent, Legal Protection}

Abstrak: Paten bisa dilihat di dalam Undang-Undang, lebih tepatnya Pasal 1 ayat 1 Undang-Undang Nomor 13 Tahun 2016. Undang- Undang telah menyebutkan bahwa pengertian hak paten adalah hak eksklusif yang diberikan oleh negara kepada inventor atas hasil invensinya di bidang teknologi selama waktu tertentu. Seorang inventor dapat melaksanakan sendiri invensinya atau memberikan persetujuan kepada pihak lain untuk melaksanakannya. Syarat mendapatkan hak paten ada tiga yaitu penemuan tersebut merupakan penemuan baru. Yang kedua, penemuan tersebut diproduksi dalam skala massal atau industrial. Suatu penemuan teknologi, secanggih apa pun, tetapi tidak dapat diproduksi dalam skala industri (karena harganya sangat mahal /tidak ekonomis), maka tidak berhak atas paten. Yang ketiga, penemuan tersebut merupakan penemuan yang tidak terduga sebelumnya (non obvious). Jadi bila sekedar menggabungkan dua benda tidak dapat dipatenkan.

Kata kunci: Paten, Perlindungan Hukum. 


\section{PENDAHULUAN}

Sejak Manusia dilahirkan diberi anugerah oleh Tuhan akal dan budi, Dengan akal dan budi tersebut manusia mampu bertindak, bersikap dan berpikir. Yang melahirkan karya cipta tentang sesuatu yang dikehendakinya. Kemampuan berpikir menghasilkan penemuan di bidang ilmu pengetahuan, teknologi yang bermanfaat untuk segala kehidupan manusia.

Setiap orang yang melakukan aktivitas dalam pengembangan kualitas kehidupan dengan menemukan teknologi yang bermanfaat bagi umat manusia yang berdampak bagi kehidupan manusia. Penemuan baru tersebut sebenarnya tidak berdiri sendiri, melainkan terkait dengan penemuan-penemuan sebelumnya. Papin, misalnya menemukan piston dengan mesin uap panas (1960) tidak lepas dari penemuan termometer dengan prinsip uap air oleh Galileo (1620). Galileo juga tidak berangkat dari nol, tetapi dia berutang budi terhadap Leonardo Da Vinci, Kopernikus, dan Kepler ${ }^{1}$.

Seiring dengan perkembangan teknologi saat ini, mempengaruhi kehidupan manusia, perkembangan tersebut sangat pesat. Perkembangan itu tidak hanya di bidang teknologi tinggi, seperti komputer, elektro, telekomunikasi dan bioteknologi tetapi juga di bidang mekanik, kimia dan lain-lain. Bahkan, sejalan dengan itu, makin tinggi pula kesadaran masyarakat untuk meningkatkan pendayagunaan teknologi yang sederhana. (Penjelasan undang-undang paten).

Di dalam pelaksanaan pembangunan nasional pada umumnya, khususnya pembangunan sektor ekonomi, teknologi memiliki peranan yang sangat penting artinya dalam usaha peningkatan dan pengembangan industri teknologi pada dasarnya adalah karya intelektual manusia. Karena penemuannya memerlukan tenaga, waktu, dan biaya yang besar, maka teknologi sebagai karya intelektual memiliki nilai dan manfaat ekonomi. Dalam ilmu hukum dan praktek secara luas dianut oleh bangsa lain, hak atas penemuan sebagai karya intelektual diakui sebagai harta kekayaan imaterial (tak berwujud) yang disebut paten. Oleh karena itu wajarlah apabila paten diberi perlindungan hukum sehingga setiap orang wajib menghargai dan menghormati hak paten orang lain.

Dalam perlindungan paten Negara Republik Indonesia telah mengeluarkan Undang-Undang No. 13 tahun 2016 tentang paten. Paten adalah hak eksklusif yang diberikan oleh negara kepada inventor atas hasil invensinya di bidang teknologi untuk

\footnotetext{
1 Ade Maman Suherman. Aspek Hukum dalam Ekonomi Global. Jakarta: Ghalia Indonesia, 2001, h. 5.
} 
jangka waktu tertentu melaksanakan sendiri invensi tersebut atau memberikan persetujuan kepada pihak lain untuk melaksanakannya.

Perlindungan paten secara Internasional baru dilakukan sejak tahun 1883 melalui The Paris Convention for The Protection of Industrial Property. Konvensi Paris bertujuan memberikan perlindungan paten secara timbal balik di antara Negara-negara peserta konvensi. Setiap Negara dapat menjadi peserta konvensi Paris dengan mengajukan permohonan. Konvensi Paris telah beberapa kali terjadi perubahan. Perubahan pertama melalui konferensi di Brussel tahun 1900, kedua di Washington tahun 1911, ketiga di Denhaag tahun 1925, keempat di London tahun 1934, kelima di Lisabon tahun 1958 dan terakhir di Stockholm tahun 1967 dimana Indonesia telah mengesahkan dan menjadi anggota WIPO (World Intellectual Property Organization) melalui keputusan Presiden no. 24 tahun 1974.

Namun pada kenyataannya masih banyak terjadi pelanggaran terhadap paten. Dalam kasus tempe, dimana tempe merupakan makanan asli Indonesia ternyata hak patennya dimiliki Negara lain. Antara lain Amerika Serikat telah memiliki 35 (tiga puluh lima) hak paten yang berhubungan dengan tempe dan Jepang memiliki 5 (lima) hak paten. Sedangkan Indonesia hanya memiliki 2 (dua) hak paten yang berkaitan dengan paten, itu pun baru tahap pendaftaran belum memiliki nomor paten. "Di dalam salah satu paten disebutkan tempe yang dicelup dengan tepung lalu digoreng. Begitu juga invensi yang dilakukan oleh Inventor yang ada di Kota Kendari, dalam hal ini produk Perak Kendari yang dikenal dengan Kendari werk, gambol Kendari yang dikenal dalam pasar nasional dan Internasional dengan Merek Naga Geni, para pengrajin menghawatirkan adanya pencaplokan/penjiplakan produk dengan mendaftarkan produk-produk pengrajin lokal di luar negeri, sehingga yang menyebabkan para pengrajin tidak bias memproduksii kerajinan yang mereka ciptakan." ${ }^{2}$ Kenyataan tersebut dikarenakan kelalaian ilmuwan Indonesia dalam pendaftaran paten atas tempe ataupun produk lainnya seperti batik. Amerika Serikat memegang 12 (dua belas) hak paten atas batik, rotan Amerika Serikat memegang hak paten 193 (seratus Sembilan puluh tiga) hak paten, Indonesia 7 (tujuh) hak paten, maupun produk lainnya, sehingga dengan leluasa Negara lain mematenkan produk

2 Jabalnur, Sikap Pengrajin Khas Daerah Sulawesi Tenggara Terhadap HAKI, Tesis, Makassar: Universitas Hasanuddin, 2009, h. 12. 
yang berharga bangsa Indonesia, selain itu kurangnya perhatian dari pemerintah Indonesia atas hasil karya cipta putra Indonesia 3 .

Dengan kasus di atas maka perlunya perlindungan hukum terhadap temuantemuan hasil karya cipta putra Indonesia. Serta perlunya pemerintah khususnya pemerintah Provinsi dan Kab/Kota dan Perguruan Tinggi memfasilitasi para pencipta dan pengrajin untuk dapat mendaftarkan karya-karya mereka. Dengan dilandasi oleh pemikiran-pemikiran tidak semua orang mempunyai kemampuan, talenta, waktu untuk menemukan sesuatu yang baru di bidang ilmu pengetahuan, teknologi, bioteknologi

Apabila tidak ada perlindungan hukum atas temuan-temuan di bidang ilmu pengetahuan, teknologi, bioteknologi. Maka setiap orang dapat memproduksi tanpa batas sehingga penemu dari temuan tersebut tidak mendapatkan nilai ekonomis. Bahkan akan merugikan penemu dan menjadikan setiap orang tidak kompetitif. Berdasarkan latar belakang masalah di atas, maka rumusan masalah yang akan dibahas dalam makalah ini adalah: Bagaimanakah prosedur pendaftaran paten? Bagaimanakah perlindungan paten di Indonesia?

\section{METODE PENELITIAN}

Tipe penelitian ini adalah penelitian hukum normatif. Menurut Bernard Arief Sidharta bahwa penelitian hukum normatif (dogmatik hukum, rechtsdogmatiek), kegiatan ilmiahnya mencakup inventarisasi, memaparkan, interpretasi, dan sistematisasi termasuk evaluasi keseluruhan hukum positif (teks otoritatif) yang berlaku dalam masyarakat atau Negara4. Jenis data yang digunakan adalah data sekunder yaitu data penelitian yang diperoleh dari kepustakaan. Pengumpulan data dalam penelitian dilakukan dengan metode dokumentasi, dan alat mengumpulkan data dilakukan melalui studi dokumen. Metode yang dipakai menganalisis data adalah metode kualitatif yaitu suatu analisis secara mendalam dan komprehensif.

3 Internet, Kompas Cyber Media, http://www.kompas/community, diakses pada tanggal 15 Februari 2017.

4 Sulistyowati Irianto dan Shidarta (ed), Metode Penelitian Hukum; Konstelasi dan Refleksi, Jakarta: Yayasan Pustakan Obor Indonesia, 2011, h. 142. 


\section{ANALISIS DAN PEMBAHASAN \\ Pengertian Paten}

Dalam Pasal 1 butir 1 Undang-Undang Nomor 13 tahun 2016, "paten merupakan hak eksklusif yang diberikan oleh negara kepada inventor atas hasil invensinya di bidang teknologi untuk jangka waktu tertentu melaksanakan sendiri invensi tersebut atau memberikan persetujuan kepada pihak lain untuk melaksanakannya."

Hak khusus bersifat eksklusif artinya hak itu hanya diberikan kepada penemu sebagai satu-satunya yang berhak atas penemuannya dan sebagai pemiliknya. Hak tersebut tetap melekat dan tidak berkurang sekalipun dikemudian hari ada pula yang berdasarkan undang-undang ini diakui sebagai penmu terdahulu. Sebagai pemilik , penemu berhak melaksanakan sendiri penemuannya itu. Apabila ada pihak lain yang ingin melaksanakan penemuan itu guna memperoleh manfaat ekonomi, maka pihak lain itu harus memperoleh izin tertulis dari penemu selaku pemilik paten. Penemuan di bidang teknologi tersebut meliputi kegiatan pemecahan masalah yang berupa:
a. Proses produksi
b. Hasil produksi
c. Penyempurnaan proses produksi
d. Pengembangan proses produksi
e. Pengembangan hasil produksi

Ide inventor yang dituangkan ke dalam suatu kegiatan pemecahan masalah yang spesifik di bidang teknologi dapat berupa produk atau proses atas penyempurnaan dan pengembangan produk dan proses.

Sedangkan menurut WIPO (World Intellectual Property Organization) yang merupakan organisasi internasional yang merupakan masalah-masalah hak milik paten adalah : "legally enforceable light granted by virtue of law to a person to exclude, for a limited time, others from certain acts in relation to described new investor".

Dimana perbuatan-perbuatan hak eksklusif dari si pemegang hak paten adalah produksi dan barang yang dipatenkan (manufacturing) penggunaan (using) dan penjualan (selling) dari barang tersebut. Dan lain-lain perbuatan yang terkait dengan penjualan barang itu seperti mengimpor dan menyimpan (stocking). 


\section{Lingkup Paten}

Paten diberikan untuk invensi yang baru dan mengandung langkah inventif serta dapat diterapkan dalam industri. Suatu invensi merupakan hal yang tidak dapat diduga sebelumnya harus dilakukan dengan memperhatikan keahlian yang ada pada saat pertama kali diajukan permohonan. Suatu invensi dapat diterapkan dalam industri, jika invensi dapat dilaksanakan dalam industri sesuai dengan apa yang diuraikan dalam permohonan. Paten yang tidak diberikan dalam invensi penemuan meliputi:

1. Proses atau produk yang penggunaannya bertentangan dengan peraturan perundang-undangan yang berlaku, moralitas agama, ketertiban umum atau kesusilaan.

2. Metode pemeriksaan, perawatan, pengobatan dan atau pembedahan yang ditetapkan terhadap manusia dan atau hewan.

3. Teori yang metode di bidang ilmu pengetahuan dan matematika atau

4. Semua makhluk hidup kecuali jasad renik, dan

5. Proses biologi yang esensial untuk memproduksi tanaman atau hewan kecuali proses non biologi atau mikro biologi.

\section{Syarat-Syarat Paten}

Ada tiga syarat utama bagi suatu penemuan untuk dapat dipatenkan. Syarat-syarat ini adalah bahwa:

1. Penemuan ini harus baru (novelty)

2. Penemuan ini harus memperlihatkan adanya suatu langkah invensi dan

3. Penemuan itu dapat digunakan di bidang industri.

Pasal 2 undang-undang nomor 13 tahun 2016 tentang paten sebagai berikut: "paten diberikan untuk invensi yang baru dan mengandung langkah inventif serta dapat diterapkan dalam industri"

\section{Pemilik dan Pemegang Paten}

Yang berhak memperoleh paten adalah penemu. Penemu adalah seorang atau beberapa orang secara bersama-sama atau badan hukum yang melaksanakan kegiatan yang menghasilkan penemuan. Yang dianggap sebagai adalah orang yang untuk pertama kali mengajukan permintaan paten kecuali terbukti sebaliknya. Pemilik paten adalah penemu yang berhak memperoleh dan sekaligus pemegang paten. Tetapi dalam hubungan kerja, 
yang berhak memperoleh dan sekaligus pemegang paten atas suatu penemuan adalah orang yang berhak atas pencantuman namanya sebagai penemu surat pemberian paten. (Abdulkadir Muhammad, 125: 1994).

\section{Sistem Pendaftaran Paten}

Ada dua sistem pendaftaran paten yang dikenal di dunia yaitu sistem registrasi dan System ujian.

1. Menurut sistem registrasi setiap permohonan pendaftaran paten diberi paten oleh kantor paten secara otomatis. Spesifikasi dari permohonan tersebut hanya memuat uraian dan monopoli yang diminta dan tidak diberi penjelasan secara rinci. Karenanya batas-batas monopoli tidak dapat diketahui sampai saat timbul sengketa yang dikemukakan di depan siding pengadilan yang untuk pertama kali akan luasnya monopoli yang diperbolehkan. Itu pula sebabnya paten-paten yang terdaftar menurut sistem registrasi tanpa penyelidikan dan pemeriksaan terlebih dahulu dianggap bernilai rendah (Saidin. OK, 239:1995).

2. Menurut sistem ujian seluruh instansi terkait diwajibkan untuk menguji setiap permohonan pendaftaran bila perlu mendesak pemohon agar mengadakan perubahan (amandemen) sebelum hak atas paten tersebut diberikan. Pada umumnya ada tiga unsur (kriteria) pokok yang diuji, yaitu:

a. Invensi harus memenuhi syarat-syarat untuk diberi hak atas paten menurut Undang-undang paten.

b. Invensi baru harus mengandung sifat kebaruan.

c. Invensi harus mengandung unsur menemukan sesuatu yang bersifat kemajuan (invention step) dari apa yang telah diketahui.

\section{Prosedur Pendaftaran Paten}

Di Negara Republik Indonesia, hak paten dirumuskan sebagai bak eksklusif yang diberikan oleh Negara kepada inventor atas hasil invensinya di bidang teknologi, yang untuk selama waktu tertentu melaksanakan sendiri invensinya tersebut atau memberikan persetujuannya kepada pihak lain untuk melaksanakannya. Dalam sistem hukum Negara Republik Indonesia, pengaturan tentang hak paten merupakan bagian dari hukum perdata, yang termasuk dalam bagian hukum benda. Termasuk dalam hak kebendaan imaterial, 
yang termasuk dalam hak kebendaan imaterial adalah hak kekayaan intelektual. Di dalam hak kekayaan intelektual termasuk di dalamnya hak paten.

Adapun standar agar dapat dinilai sebagai hak paten apabila memenuhi tiga syarat utama bagi suatu penemuan untuk dapat dipatenkan. Syarat-syarat ini adalah bahwa:

a. Penemuan ini harus baru (novelty)

b. Penemuan ini harus memperlihatkan adanya suatu langkah inventif, dan

c. Penemuan itu dapat digunakan di bidang industri.

Pasal 2 Undang-undang nomor 13 tahun 2016 tentang paten sebagai berikut: "paten diberikan untuk invensi yang baru dan mengandung langkah inventif serta dapat diterapkan dalam industri".

Yang berhak memperoleh paten adalah penemu. Penemu adalah seorang atau beberapa orang secara bersama-sama atau badan hukum yang melaksanakan kegiatan yang menghasilkan penemuan. Yang dianggap sebagai penemu adalah orang yang untuk pertama kali mengajukan permintaan paten kecuali jika terbukti sebaliknya. Pemilik paten adalah penemu yang berhak memperoleh dan sekaligus pemegang paten.

Untuk memperoleh paten, penemu selaku pemilik paten mengajukan kepada kantor paten dirjen hak cipta, paten dan merek Departemen Hukum dan HAM dengan memenuhi syarat sebagaimana diatur dalam Undang-Undang no. 13 tahun 2016 tentang paten.

Adapun Syarat dan tata cara permohonan, sesuai dengan pasal 24 Undang-undang nomor 13 tahun 2016 adalah:

(1) Paten diberikan berdasarkan Permohonan.

(2) Permohonan sebagaimana dimaksud pada ayat (1) diajukan oleh Pemohon atau Kuasanya kepada Menteri secara tertulis dalam bahasa Indonesia dengan membayar biaya.

(3) Setiap Permohonan diajukan untuk satu Invensi atau beberapa Invensi yang merupakan satu kesatuan Invensi yang saling berkaitan.

(4) Permohonan sebagaimana dimaksud pada ayat (2) dapat diajukan baik secara elektronik maupun non elektronik.

Surat permohonan harus disertai :

(1) Permohonan sebagaimana dimaksud dalam Pasal 24, paling sedikit memuat:

a) Tanggal, bulan, dan tahun surat Permohonan;

b) nama, alamat lengkap, dan kewarganegaraan Inventor; 
c) nama, alamat lengkap, dan kewarganegaraan Pemohon dalam hal Pemohon adalah bukan badan hukum;

d) nama dan alamat lengkap Pemohon dalam hal Pemohon adalah badan hukum;

e) nama, dan alamat lengkap Kuasa dalam hal Permohonan diajukan melalui Kuasa; dan

f) nama negara dan Tanggal Penerimaan Permohonan yang pertama kali dalam hal Permohonan diajukan dengan Hak Prioritas.

(2) Permohonan sebagaimana dimaksud pada ayat (1) harus dilampiri persyaratan:

a) judul Invensi;

b) deskripsi tentang Invensi;

c) klaim atau beberapa klaim Invensi;

d) abstrak Invensi;

e) gambar yang disebutkan dalam deskripsi yang diperlukan untuk memperjelas Invensi, jika Permohonan dilampiri dengan gambar;

f) surat kuasa dalam hal Permohonan diajukan melalui Kuasa;

g) surat pernyataan kepemilikan Invensi oleh Inventor;

h) surat pengalihan hak kepemilikan Invensi dalam hal Permohonan diajukan oleh Pemohon yang bukan Inventor; dan

i) surat bukti penyimpanan jasad renik dalam hal Permohonan terkait dengan jasad renik.

(3) Deskripsi tentang Invensi sebagaimana dimaksud pada ayat (2) huruf b harus mengungkapkan secara jelas dan lengkap tentang bagaimana Invensi tersebut dapat dilaksanakan oleh orang yang ahli di bidangnya.

(4) Klaim atau beberapa klaim Invensi sebagaimana dimaksud pada ayat (2) huruf c harus mengungkapkan secara jelas dan konsisten atas inti Invensi, dan didukung oleh deskripsi sebagaimana dimaksud pada ayat (3).

\section{Perlindungan Paten Di Indonesia}

Perlindungan paten pertama kali secara internasional dilakukan sejak tahun 1883 melalui The Paris Concention for The Protection of Industrial Property. Baru pada tahun 1989 Negara Republik Indonesia mengeluarkan Undang-undang No. 6 Tahun 1989 tentang 
Paten. Dan kemudian pada tahun 1994 Indonesia meratifikasi Agreement Establishing The World Trade Organization Undang-Undang No. 7 Tahun 1994. Pada tahun 2001, Undangundang Paten diperbaharui dengan Undang-undang No. 14 Tahun 2001, saat ini per tanggal 26 Agustus 2016 telah dikeluarkan Undang-Undang Paten terbaru, UndangUndang No. 13 Tahun 2016 Tentang Paten. Yang memberikan penjelasan secara lengkap tentang paten.

Adapun Ruang lingkup perlindungan paten di Indonesia sesuai dengan Undangundang No. 13 Tahun 2016 tentang Paten yang terbaru, meliputi penemuan yang dapat diberikan paten, penemuan yang tidak dapat diberikan paten, subyek paten, hak dan kewajiban pemegang paten dan pengecualian terhadap pelaksanaan dan pelanggaran paten.

Setiap orang wajib menghormati paten orang lain dan tidak boleh dilaksanakan oleh pihak lain tanpa izin tertulis dari pemilik selaku pemegang paten. Perlindungan paten berlaku selama 20 (dua puluh) tahun semenjak tanggal penerimaan. Adapun untuk paten sederhana diberikan jangka waktu 10 tahun. Dengan perlindungan hukum tersebut, pemegang paten bukan saja memperoleh jaminan, tetapi juga memiliki dasar untuk mempertahankan haknya.

Apabila terjadi pelanggaran paten yang dilakukan dengan sengaja dan tanpa hak, sehingga menimbulkan kerugian bagi pemegang paten atau pemegang lisensi, maka pemegang paten atau lisensi yang bersangkutan berhak menyelesaikan sengketa secara alternatif melalui arbitrase sesuai pasal 153 Undang-Undang No. 13 Tahun 2016 Tentang Paten, pemegang paten atau penerima lisensi berhak mengajukan gugatan ganti rugi ke pengadilan Niaga sesuai pasal 143. Apabila tuntutan itu dikabulkan, maka panitera segera menyampaikan putusan kepada Kantor Paten untuk selanjutnya dicatat dalam Daftar Umum Paten dan diumumkan dalam Berita Resmi Paten.

Hak menuntut secara perdata tidak mengurangi hak negara untuk menuntut secara pidana terhadap pelanggaran paten. Adapun pelanggaran pidana yang diatur dalam Undang-undang No. 13 Tahun 2016 tentang Paten sebagai berikut:

1. Pasal 161 "Setiap Orang yang dengan sengaja dan tanpa hak melakukan perbuatan sebagaimana dimaksud dalam Pasal 160 untuk Paten, dipidana dengan pidana penjara paling lama 4 (empat) tahun dan/atau denda paling banyak Rp 1.000.000.000,00 (satu miliar rupiah). 
2. Pasal 162 "Setiap Orang yang dengan sengaja dan tanpa hak melakukan perbuatan sebagaimana dimaksud dalam Pasal 160 untuk Paten sederhana, dipidana dengan pidana penjara paling lama 2 (dua) tahun dan/atau denda paling banyak Rp500.000.000,00 (lima ratus juta rupiah).

3. Pasal 163

(1) Setiap orang yang melanggar ketentuan sebagaimana dimaksud dalam Pasal 161 dan/atau Pasal 162, yang mengakibatkan gangguan kesehatan dan/atau lingkungan hidup, dipidana dengan pidana penjara paling lama 7 (tujuh) tahun dan/atau denda paling banyak Rp2.000.000.000,00 (dua miliar rupiah).

(2) Setiap orang yang melanggar ketentuan sebagaimana dimaksud dalam Pasal 161 dan/atau Pasal 162, yang mengakibatkan kematian manusia, dipidana dengan pidana penjara paling lama 10 (sepuluh) tahun dan/atau denda paling banyak Rp3.500.000.000,00 (tiga miliar lima ratus juta rupiah).

4. Pasal 164 "Setiap Orang yang dengan sengaja dan tanpa hak membocorkan dokumen Permohonan yang bersifat rahasia sebagaimana dimaksud dalam Pasal 45 ayat (1) dipidana dengan pidana penjara paling lama 2 (dua) tahun. Adapun konsiderans pasal 19 yaitu:

A. Ayat (1) Pemegang Paten memiliki hak eksklusif untuk melaksanakan Paten yang dimilikinya dan untuk melarang pihak lain yang tanpa persetujuannya:

(1) dalam hal Paten-produk: membuat, menggunakan, menjual, mengimpor, menyewakan, menyerahkan, atau menyediakan untuk dijual atau disewakan atau diserahkan produk yang diberi Paten;

(2) dalam hal Paten-proses: menggunakan proses produksi yang diberi Paten untuk membuat barang atau tindakan lainnya sebagaimana dimaksud dalam huruf a.

B. Ayat (2) Larangan menggunakan proses produksi yang diberi Paten sebagaimana dimaksud pada ayat (1) huruf $b$, hanya berlaku terhadap impor produk yang semata-mata dihasilkan dari penggunaan proses yang diberi pelindungan Paten. 
C. Ayat (3) Dalam hal untuk kepentingan pendidikan, penelitian, percobaan, atau analisis, larangan sebagaimana dimaksud pada ayat (1) dan ayat (2) dapat dikecualikan sep

\section{KESIMPULAN}

Dari uraian di atas dalam pembahasan perlindungan hak paten, maka dapat ditarik kesimpulan sebagai berikut:

a. Yang berhak memperoleh paten adalah penemu yang disebut inventor. Penemu adalah seseorang atau beberapa orang atau badan hukum, yang melaksanakan kegiatan yang menghasilkan penemuan. Yang dianggap sebagai penemu adalah orang yang untuk pertama kali mengajukan permintaan paten kecuali terbukti sebaliknya. Pemilik paten adalah penemu yang berhak memperoleh dan sekaligus pemegang paten, sesuai dengan pasal 24 ayat 1, 2, 3 dan 4 serta Pasal 25 ayat 1, 2, 3, dan 4 Undang-undang nomor 13 tahun 2016.

b. Setiap orang wajib menghormati paten orang lain dan tidak boleh dilaksanakan oleh pihak lain tanpa izin tertulis dari pemilik selaku pemegang paten. Setiap Orang yang dengan sengaja dan tanpa hak melakukan perbuatan sebagaimana dimaksud dalam Pasal 160 untuk Paten, dipidana dengan pidana penjara paling lama 4 (empat) tahun dan/atau denda paling banyak Rp 1.000.000.000,00 (satu miliar rupiah). Pasal 162 Setiap Orang yang dengan sengaja dan tanpa hak melakukan perbuatan sebagaimana dimaksud dalam Pasal 160 untuk Paten sederhana, dipidana dengan pidana penjara paling lama 2 (dua) tahun dan/atau denda paling banyak Rp500.000.000,00 (lima ratus juta rupiah). Pasal 163 (1) Setiap orang yang melanggar ketentuan sebagaimana dimaksud dalam Pasal 161 dan/atau Pasal 162, yang mengakibatkan gangguan kesehatan dan/atau lingkungan hidup, dipidana dengan pidana penjara paling lama 7 (tujuh) tahun dan/atau denda paling banyak Rp2.000.000.000,00 (dua miliar rupiah).

(2) Setiap orang yang melanggar ketentuan sebagaimana dimaksud dalam Pasal 161 dan/atau Pasal 162, yang mengakibatkan kematian manusia, dipidana dengan pidana penjara paling lama 10 (sepuluh) tahun dan/atau denda paling banyak Rp3.500.000.000,00 (tiga miliar lima ratus juta rupiah). Pasal 164 Setiap Orang yang dengan sengaja dan tanpa hak membocorkan dokumen Permohonan yang bersifat rahasia sebagaimana dimaksud dalam Pasal 45 ayat (1) dipidana dengan pidana 
penjara paling lama 2 (dua) tahun. Pasal 165 Tindak pidana sebagaimana dimaksud dalam Pasal 161, Pasal 162, dan Pasal 164 merupakan delik aduan.

\section{Daftar Pustaka}

Jabalnur, Sikap Pengrajin Khas Daerah Sulawesi Tenggara Terhadap HAKI, Tesis, Makassar: Universitas Hasanuddin, , 2009

Muhammad, Abdulkadir, Hukum Harta Kekayaan, Bandung: Citra Aditya Bakti, 1994. Kajian Hukum Ekonomi Hak Kekayaan Intelektual, Bandung: Citra Aditya Bakti, 2001.

Riwandi, Budi Agus \& M. Syamsudin, Hak Kekayaan Intelektual dan Budaya Hukum. Jakarta: Raja Grafindo Persada, 2005.

Saidin, OK., Aspek Hukum Kekayaan Intelektual, Jakarta: Raja Grasindo Persada , 1995.

Suherman, Ade Maman, Aspek Hukum dalam Ekonomi Global: Jakarta: Ghalia Indonesia, 2001.

Undang-Undang HAKI, Sinar Grafika, Jakarta 